\title{
Diet in chronic kidney disease in a Mediterranean African country
}

\author{
Khawla Kammoun ${ }^{1,2^{*}}$, Hanen Chaker ${ }^{1,2}$, Hichem Mahfoudh ${ }^{1,2}$, Nouha Makhlouf ${ }^{1}$, Faical Jarraya ${ }^{1,2}$ and \\ Jamil Hachicha ${ }^{1,2}$
}

\begin{abstract}
Background: Mediterranean diet is characterized by low to moderate consumption of animal protein and high consumption of fruits, vegetables, bread, beans, nuts, seeds and other cereals. It has been associated with reduced risk of cardiovascular disease. However, it is not suitable for chronic kidney disease because of high potassium intake.

Discussion: Tunisia is an emerging Mediterranean country with limited resources, a high prevalence of chronic hemodialysis treatment and high dialysis expenditures. In order to limit dialysis cost, primary and secondary prevention of chronic renal disease are of paramount importance. In addition to drugs, secondary prevention includes diet measures (e.g. salt diet, protein diet). The aims of diet practice in chronic kidney disease are to slow chronic renal failure progression and to prevent its complications like hyperphosphatemia and hyperkaliemiae. A few decades ago, a Tunisian diet was exclusively Mediterranean, and protein consumption was not excessive. However, today, protein consumption is more comparable to western countries. Salt consumption is also excessive. Some Tunisian diets still include food with high potassium intake, which are not suitable for patients with chronic kidney disease. Therefore, the role of the dietician is extremely important to help calculate and create a dietary regimen tailored to each of our patients.
\end{abstract}

Summary: Advice about diets should be adapted to both the patient and population habits to improve adherence rate. As such, the purpose of this article is to provide our own experience regarding medical nutrition therapy in patients with chronic kidney disease in Tunisia, with some changes in food habits. Prevention is far better than treatment. In this perspective, dietary measures must be at the core of our intervention.

Keywords: Chronic renal failure, Diet, Low protein diet, Phosphorus, Potassium, Sodium

\section{Background}

Tunisia is an emerging country with limited resources (https://en.wikipedia.org/wiki/Emerging_markets\#cite_note-2, https://www.theisn.org/images/Membership/Eli gible_Countries_for_Joint_Membership_Jan_2016.pdf, https://datahelpdesk.worldbank.org/knowledgebase/articles/378834-how-does-the-world-b). Chronic hemodialysis treatment begun in Tunisia in 1963 with a very strict selection. Only young people with social insurance, and without severe co morbidities (like neoplasia or severe heart disease) were treated with dialysis. End stage renal disease incidence rose from 81.6 per million people (pmp) to 137 in $2007[1,2]$.

\footnotetext{
* Correspondence: KhawlaKammoun2002@yahoo.fr

${ }^{1}$ Neprology Department Hedi Chaker Hospital, Sfax, Tunisia

${ }^{2}$ Renal Pathology Unit, UR 12 ES 14 Medecin, University Sfax Tunisia, Sfax, Tunisia
}

(c) The Author(s). 2017 Open Access This article is distributed under the terms of the Creative Commons Attribution 4.0 International License (http://creativecommons.org/licenses/by/4.0/), which permits unrestricted use, distribution, and reproduction in any medium, provided you give appropriate credit to the original author(s) and the source, provide a link to the Creative Commons license, and indicate if changes were made. The Creative Commons Public Domain Dedication waiver (http://creativecommons.org/publicdomain/zero/1.0/) applies to the data made available in this article, unless otherwise stated.

This sharp increase could be linked to a political decision made in 1991 to treat all patients, regardless of their social insurance and comorbidities, but without significant increased number of renal transplantation which was at $14 \mathrm{pmp}$ in 2007. Prevalence of renal replacement therapy (RRT) in December 2007 was 713 pmp [2]. Sfax is a southern Tunisian city, with one million population. According to the last regional registry data in 2014 RRT prevalence was 771 patients.

The main causes of end stage chronic kidney disease are unknown nephropathy [3]. Increase in the prevalence of ESRD treated with dialysis has led to an increase in costs of dialysis treatment, and dialysis expenditures represented $4.5 \%$ of Tunisian Health budget in 2000 [1]. Primary and secondary CKD prevention is therefore essential to our country which has limited resources. Primary prevention aims to decrease CKD incidence. Secondary 
prevention aims to slow renal function decline. They include not only therapeutic measurement such as control of hypertension, diabetes, but also lifestyle and dietary measures such as restricting sodium and protein intake.

Protein intake is still low in several Sub-Saharan African countries [4]. In Tunisia, protein intake appears to be adequate and similar to that observed in migrant Tunisian people living in France and local born French people [5]. In our center, we conducted a dietary intake evaluation prospective study of 100 consecutive CKD patients. Mean protein intake was $1.48 \pm 0,4 \mathrm{~g} / \mathrm{kg} / \mathrm{d}$ (0.73-3 g/kg/d). We found that only 6 patients had a protein intake $<1 \mathrm{~g} / \mathrm{kg} / \mathrm{d}$ and 4 patients had a protein intake exceeding $2 \mathrm{~g} / \mathrm{kg} / \mathrm{d}$ [data not published].

Since the Brenner theories of increased workload on the remnant nephrons, and its prevention by decreasing protein intake [6], use of low protein diet for patients with renal damage in patients with CKD is a subject of controversy between supporters and adversaries [7, 8]. Complications of renal failure such inflammation and acidosis lead to hypercatabolism by activating enzymes that breakdown proteins. However, hypercatabolism is not stopped by protein intake increase. An increase in protein intake will worsen acidosis and accumulation of potential uremic toxins and development of uremic symptoms without increasing muscle mass $[9,10]$. It has been shown that protein intake reduction in patients with moderate chronic kidney failure reduces blood chemistry abnormalities like acidosis, phosphorus and urea [11].

The main objective of any diet practice in patients with CKD is to slow chronic renal failure progression without inducing malnutrition. So before any prescription of protein diet, a nutrition assessment status should be performed. Regular nutritional assessment should be conducted every 2-3 months for non-dialysed out-patients with glomerular filtration rate (GFR) $<20 \mathrm{ml} / \mathrm{mn}$ is recommended [12]. Screening for malnutrition should be more frequent when there is a malnutrition risk event. There are many methods for screening malnutrition, but the method selected should be simple, reproducible and not expensive [12].

The nutritional status assessment should be based on a group of clinicobiological parameters, which we employ in our center. These parameters should be inexpensive, reproducible and accessible in routine practice.

\section{Antrophometric parameters}

Measurements of height, actual body weight and its comparison to an anterior body weight or to an ideal weight, and body mass index (BMI) calculation are easy simple and inexpensive methods to assess nutritional status. In our center, these evaluations are conducted at each visit by a nephrologist. However, one limitation of this method is body sensitivity to hydration modification status [12]. Measurement of four skinfold thicknesses (biceps, triceps, subscapular, and suprailiac) is a validated method to estimate fat mass and lean body mass. We carried out a cross sectional study in hemodialysed patients, which involved comparisons between routine anthropometric measurements and skinfold thicknesses measurements, and found a significant correlation between BMI and skin-fold measurements. However, unlike BMI, these techniques need an experienced technician and is time consuming. As such, it cannot be used in routine practice $[13,14]$.

\section{Laboratory assessment}

Serum proteins that are considered as nutritional markers are albumin, prealbumin tranferrin, and retinol binding protein, but no serum protein has been found to be specific for malnutrition. No biological marker has a high sensitivity, or specificity for screening nutritional state, and the protein sensitivity for nutrition assessment depends on the duration of their individual half-lives. Their concentration could also change in other physiologic and pathological situations [13, 15-20]. In our center, serum albumin is used to evaluate nutritional status when malnutrition is clinically suspected. In Tunisia, assessment of serum albumin levels is recommended every 6 months in dialyzed patients. There is no national recommendation in non-dialyzed CKD patients.

\section{Index Score - subjective global assessment (SGA)}

Malnutrition is one of the main important risk factors of inflammation and atherosclerosis in chronic renal failure. Several studies have shown that physical examination scores like subjective global assessment (SGA), malnutrition inflammation score (MIS) and nutritional risk screening (NRS) detect prognostic of malnutrition more reliably than laboratory parameters alone [21]. It can recognize various degrees of malnutrition that may remain undetected by a single laboratory parameter [22]. SGA can be used to determine malnutrition outcome, and as such is more commonly used [23].

The SGA score is correlated to anthropometric parameters such as mild arm circumference and skinfold measurement. It is a simple method using clinical and anthropometric parameters that are easy to evaluate [24]. In a cross-sectional study in hemodialyzed patients, we demonstrated that SGA has a high specificity (86\%) and a good positive predictive value compared to estimation of fat and lean mass using four skinfold thicknesses (biceps, triceps, subscapular, and suprailiac) and arm circumference [14]. SGA is recommended by the European Best Practice Guidelines on Nutrition and the national kidney foundation as a valid method to identify patients at risk of malnutrition $[25,26]$.

In our practice, when a patient is identified as suffering from malnutrition, serum albumin levels are checked, and 
the patient is referred to the dietician who evaluates their nutritional status using SGA, and will prescribe dietary advice according to their nutritional status, CKD stage and co morbidities.

\section{Protein diet}

When prescribing protein intake, normal, low and high protein intake should be defined. However, normal protein intake definition is not clear. It should be a diet containing a minimum requirement to avoid deficit but also a not surpassing an ideal intake. The recommended protein intake is the daily intake level sufficient to meet the nutriment requirement of $97-98 \%$ of healthy people (https://ods.od.nih.gov/Health_Information/Dietary_Reference_Intakes.aspx) [27]. The recommended daily protein intake of healthy individuals is $0.83 \mathrm{~g} / \mathrm{kg} /$ day [28].

An intake of $0.66 \mathrm{~g} / \mathrm{kg} /$ day is accepted as average intake. The safe level of intake is equivalent to 0.83 of high quality protein [29].

In most studies restrictive protein and phosphorus diet delay glomerular filtration decline. But low protein diet $<0.6 \mathrm{~g} / \mathrm{kg}$ is not recommended because their benefit is little and they increase malnutrition risk [30].

In our center we do not prescribe a restrictive diet below $0.6 \mathrm{~g} /$ day. A more restrictive diet needs a very strict monitoring of nutrition state and it has been shown not to have a significant benefit in many studies [31]. Moreover we have only one dietitian for 120 regular dialyzed patients and 2000 hospitalizations and 2000 consultations per year. In practice, after the second or the third nephrology consultation, patients with chronic renal failure, are referred to dietician for diet advice. Our dietician performs a nutritional status assessment using a anthropometric parameters (weight, height, and body mass index a dietary) and SGA. Following this, the patient is provided with diet advice and meal menu examples based on their Tunisian habits and lifestyle (Tables 1, 2 and 3). In general practice, for patients with middle and high socioeconomic status, the dietician will advise patients to eat animal protein (such as meat and fish) for either lunch, or dinner (Tables 1, 2 and 3).

\section{Phosphorus}

Hyperphosphataemia is an ineluctable consequence of chronic renal failure with serious complications at short, middle and long term outcomes. Hence, it is a veritable challenge of the nephrologist in the follow up of his patients. Some authors have emphasized the importance of early and effective control of phosphate load before hyperphosphataemia develops to prevent the increase in PTH and FGF23 and maintain near-normal phosphorus levels for longer as CKD progresses [32].
Table 1 Example 1: for a $60 \mathrm{~kg}$ women: $1550 \mathrm{Kcal}, 53 \%$ carbohydrates, 12\% protides and 35\% lipids $2400 \mathrm{mg} \mathrm{K+,} 849 \mathrm{Ph}$

\begin{tabular}{ll}
\hline & Menu's examples \\
\hline breakfast & Milk $200 \mathrm{ml}$ \\
& bread: $50 \mathrm{~g}$ \\
& olive oil $1 \mathrm{ts}^{\mathrm{a}}$ \\
& 1 fruit \\
& Vegetables ${ }^{\mathrm{b}}: 200 \mathrm{~g}$ \\
& meat or fish $80 \mathrm{~g}$ \\
& rice or paste $300 \mathrm{~g}$ or white bread:120g \\
lunch & olive oil $1 \mathrm{cs}$ \\
& Vegetables ${ }^{\mathrm{b}}: 200 \mathrm{~g}$ \\
& meat: 0 \\
dinner & rice or paste $200 \mathrm{~g}$ or white bread:80 g \\
& olive oil $1 \mathrm{ts}^{\mathrm{a}}$ \\
& 1 fruit $^{\mathrm{c}}$ \\
\hline
\end{tabular}

${ }^{a}$ ts: tablespoon; ${ }^{b}$ double cooked; ${ }^{c}$ : 1 fruit $=1$ apple $=1$ peach $=3$ apricot $=50 \mathrm{~g}$ grenade

Dietary measure are crucial in hyperphosphatemia, even if drugs are needed.

In this approach, patient, nephrologist and dietician together form an equilateral triangle with the apex as the patient. Collaboration with dietician improves dietary compliance. Restriction of food containing phosphorus is not prescribed until hyperphosphatemia is present $[28,32]$. It has been shown that dairy intake significantly increased the serum phosphorus concentration at different DFG levels [29, 32, 33], so they must be

Table 2 Example 2: for a $60 \mathrm{~kg}$ women: $1550 \mathrm{Kcal}, 53 \%$ carbohydrates, $12 \%$ protides and 35\% lipids $2400 \mathrm{mg} \mathrm{K+,} 849 \mathrm{Ph}$

\begin{tabular}{ll}
\hline & Menu's examples \\
\hline Breakfast & Milk $200 \mathrm{ml}$ \\
& bread: $50 \mathrm{~g}$ \\
& olive oil $1 \mathrm{ts}^{\mathrm{a}}$ \\
& 1 fruit, 1 yogurt \\
& Vegetables ${ }^{\text {b. } 200 \mathrm{~g}}$ \\
& 1 egg \\
lunch & rice or paste $300 \mathrm{~g}$ or white bread:120g \\
& olive oil 1 cs \\
& Vegetables ${ }^{\text {b }} 200 \mathrm{~g}$ \\
& meat : 0 \\
dinner & rice or paste $200 \mathrm{~g}$ or white bread:80 g \\
& olive oil $1 \mathrm{ts}^{\mathrm{a}}$ \\
& 1 fruit $^{\mathrm{c}}, 1$ yogurt \\
\hline
\end{tabular}

${ }^{a}$ ts: tablespoon; ${ }^{b}$ double cooked; ${ }^{c}: 1$ fruit $=1$ apple $=1$ peach $=3$ apricot $=50 \mathrm{~g}$ grenade

Vegetables example 1: double cooked Chard, Spinach Vegetables example 2: Tunisian salad: finely chopped Cucumber + tomato+onion+Pepper 
Table 3 Example 3: for a $70 \mathrm{~kg}$ men: $2000 \mathrm{Kcal}, 49 \%$ carbohydrates, 12\% proteins and 39\% lipids $2196 \mathrm{mg} \mathrm{K+,}$ $998 \mathrm{mg} \mathrm{Ph}$

\begin{tabular}{ll}
\hline & Menu's examples \\
\hline breakfast & Milk $200 \mathrm{ml}$ \\
& bread: $80 \mathrm{~g}$ \\
& olive oil $1 \mathrm{cs}$ \\
& 1 yaourt \\
& Vegetables ${ }^{\mathrm{b}}: 200 \mathrm{~g}$ without potatoes \\
& meat $100 \mathrm{~g}$ \\
lunch & rice or paste ex $300 \mathrm{~g}$ \\
& olive oil $1 \mathrm{ts}$ \\
& Vegetables ${ }^{\mathrm{b}}: 200 \mathrm{~g}$ without potatoes \\
& meat: 0 \\
dinner & rice or paste $250 \mathrm{~g}$ \\
& olive oil $1 \mathrm{ts}^{\mathrm{a}}$
\end{tabular}

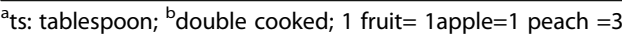
apricot $=50 \mathrm{~g}$ grenade

consumed with moderation. However, some aliments are prohibited, because of the high content of phosphorus, potassium and sodium like soft drinks, and canned foods. Some other foods have high phosphorus and sodium content (such as processed and melted cheese, delicatessen and aliments with phosphorus additives) should be also avoided.

Our experience of diet management is based on a preliminary upkeep with the nephrologist who explains the risk of hyperphosphataemia to the patient, and that the main treatment is the reduction of aliments rich in phosphorus (e.g. dairy, legumes, meat, complete cereals, dried fruit, and soda drinks). The patient is then referred to department dietician. As mentioned previously, our department has only one dietician for 120 dialyzed patients and 2000 hospitalizations and 2000 consultations per year. For external consultation the dietician provides weekly consultations for CKD and hypertensive patients The dietitian begins with a food consumption survey in order to detect the patient's excess. (The phosphorus intake should be $800-1000 \mathrm{mg} / \mathrm{d}$ ). They explain to the patient that some food products must be avoided because of their high phosphorus and sodium content, such as octopus and particularly cuttlefish, which is consumed excessively in our local area, as many coastal towns in this region have high fish consumption. Some food products should be taken in moderation, such as dairy, legumes, meat, complete cereals and dried fruit (Table 4).

It is common in our region that men and elderly people don't cook for themselves when they do not live alone. If the patient confirms that they will not be preparing their own food, our dietician will ensure that they discuss diet changes and the new recipes with the person
Table 4 Phosphorus concentrations in examples of food regularly taken in our Habits

\begin{tabular}{lll}
\hline & Mg/100 g (Ph) & G/100g(proteins) \\
\hline Veal, Lamb, beef & $115-202$ & $24,6-30$ \\
poultry (Chicken, Turkey) & $170-200$ & $23-28$ \\
barley semolina & $296 \mathrm{mg}$ & 10,5 \\
Chickpea & 139 & 8,9 \\
Sorghum & 287 & 11,3 \\
octopus, squid, cuttlefish & 127 & 16 \\
Whiting & 196 & 18,7 \\
sea bass & 256 & 22,4 \\
sea mullet & 244 & 24,8 \\
grilled sardine & 320 & 30 \\
tuna & 220 & $23,7-29,9$ \\
Canned Sardine & 490 & 23 \\
Canned Tuna & 267 & 25,6 \\
\hline
\end{tabular}

who will be preparing the patients' food, again, to help improve adherence to the new diet. These recipes should be adapted to the patient's socio-demographic characteristics. For example, the rural patient does not have the same meal habits as those living in towns or cities. In fact, in our geographic region, eating meals prepared outside of the home is more common in in cities where there is greater animal product consumption, while vegetable staples and full grain are generally consumed more in rural regions. It is therefore very important that the dietician works closely with the patient and their family to obtain a clear understanding of their meal habits so that they can create meal examples that cater to the patient's habits and lifestyle. If the patient is provided with a diet plan that has been tailored to their lifestyle, then the patient is more likely to adhere to these changes.

\section{Iron}

Iron is one of the minerals that should be given special attention [17]. The general population requires 10$15 \mathrm{mg} /$ day of iron, but patients with renal failure and ferritin levels $<100 \mathrm{mg} / \mathrm{dL}$ should receive supplements of at least $60 \mathrm{mg} /$ day of ferrous sulfate. Concomitant intake of iron with a citrus juice, promoting iron absorption together with vitamin $C$, may be suggested. The choice of a specific iron drug can be based on price, since the published literature contains few comparative studies which establish the superiority of a particular agent. Generic ferrous sulfate, $325 \mathrm{mg}$ orally 3 times daily between meals, supplies $195 \mathrm{mg}$ of elemental iron and may be an appropriate choice. If gastrointestinal side effects develop with oral iron supplements, the dose should be decreased. Clinicians should not react to gastric distress by instructing 
patients to take the supplements with meals, which will result in greatly limited iron absorption.

\section{Vitamin D}

Vitamin D is commonly deficient in chronic renal failure. This finding could be explained by a combination of factors, including poor nutrition, gastrointestinal disorders, or a lack of vitamin D synthesis because of little exposure to sun light [34]. Severe deficiency causes hypocalcaemia and induces hyperparathyroidism. Vitamin D is found in some foods, and from dermal synthesis from sun exposure. As such, supplementation is commonly needed, however the quota from animal proteins may protect from severe deficits [35]. It is commonly known that animal proteins are rich of vitamin $\mathrm{D}$ (for example, tuna, sardines, eggs, and veal liver). Nevertheless, vegetables aren't a common source of vitamin D, with the exception of mushrooms, which isn't currently consumed in our region.

The inconvenience of these aliments reside on their high phosphorus content (for example eggs), or uric acid (tuna, sardines).

Therefore, the role of dietician and their guidance is paramount when selecting the patient's food choices in order to consume the adequate quantity of animal proteins which will provide the body with the essential amino acids for tissue repair, and hormone synthesis without inducing excess consumption of phosphorus.

The dietician must calculate and integrate the patient's need for calories, vitamins, amino acids and hormones, and the result is a recipe that has been adapted specifically to the eating patient's habits.

This is a very demanding role for the dietician, and it is therefore important that the national authorities are made more aware about the need to increase the number of dieticians in public hospitals. It is an ineluctable issue in the future, especially with the outbreak of the obesity, diabetes, hypertension and chronic renal failure. A cross sectional national study, conducted in 2012, showed that hypertension, obesity, diabetes and metabolic syndrome among 35-70 years old people was $30.6 \%, 27.3 \%, 9.1 \%$ and $30 \%$ more frequent in women living in urban regions, respectively [36] (http://www.letemps.com.tn/article/88107/sant\%C3\%A9-lutte-contre-1\%E2\%80\%9 9hypertension-le-diab\%C3\%A8te-1\%E2\%80\%99ob\%C3\%A9si t\%C3\%A9-et-les-maladies-cardiaques-pour). Prevention has always been far away better than treatment, and with this in mind, the diet therefore must be in the core of our intervention.

\section{Sodium}

There is a close link between sodium intake and progression of renal disease, but with an increased consumption in dietary salt, people are becoming more accustomed to having high salt content in their food.
Dietary salt sources in Tunisian are different to those in Europe for example. Interestingly, table salt, preprepared or processed food is not the major source of dietary salt - salt added to food only represents $0.25 \%$ of salt consumption in the Tunisian diet. In our population the primary source comes from bread, which is not only rich in salt, but it forms the basis of the daily diet in Tunisia, and represents $30 \%$ of salt consumption. Other traditional sources of salted food, such as dried meat, are not as common today.

In December 2014, a press communication from the Tunisian Ministry of Health indicated that daily mean consumption of salt in Tunisia is $10 \mathrm{~g} /$ person. With an aim to reduce salt consumption to $5 \mathrm{~g} /$ day, new strategies were proposed by the Ministry of Heath with a focus on reducing salt use in bread in a pilot study in the city of Bizerte (http://www.letemps.com.tn/article/88107/ sant\%C3\%A9-lutte-contre-1\%E2\%80\%99hypertension-le-dia b\%C3\%A8te-1\%E2\%80\%99ob\%C3\%A9sit\%C3\%A9-et-les-ma ladies-cardiaques-pour). In addition, a cost effectiveness analysis of salt reduction policies to reduce coronary heart disease was conducted in Mediterranean countries, including Tunisia. It concluded that a comprehensive strategy of health education and food industry actions to label and reduce salt content would save both money and lives $[37,38]$.

Whilst we are waiting for the results from the pilot study, we continue to educate our patients about dietary salt. When salt restriction is recommended, the patient is requested to limit bread and preserved food use, especially canned tomatoes, peppers, tuna and sardines, which are widely used in Tunisian food. This can be a difficult task in a poor country, where bread is the cheapest food in Tunisia, and tuna and sardines are easy to come by in coastal regions. In a CKD patient's clinical follow-up, salt consumption is evaluated by considering the total amount of $24 \mathrm{~h}$ urine sodium. This checkup is not frequently used by nephrologists; however, advice regarding salt restriction is commonly given to patients.

\section{Potassium (K+)}

In Tunisia, a Mediterranean diet is predominant, and as such, a high amount of vegetables and fruits are consumed which leads to a high potassium intake. If such a diet is recommended for cardiovascular protection, in the very high cardiovascular risk CKD patient, it becomes problematic. When serum potassium levels are at high normal range, we recommend patients to avoid dates, the highest potassium content product, largely consumed as a fruit in Tunisia. For the others, we recommend a diet with a reduced intake of specific high potassium foods, such as bananas, dried fruits, almonds, vegetables and chocolate (Table 5). Our advice is not to soak vegetables in water, which is not effective at reducing potassium levels, but instead double cook them (for 
Table 5 Potassium concentrations in examples of food regularly taken in our habits

\begin{tabular}{ll}
\hline & $(\mathrm{K}+) \mathrm{Mg} / 100 \mathrm{~g}$ \\
\hline datte & $2600 \mathrm{mg}$ \\
barley semolina & 309 \\
Chickpea & 168 \\
dry bean & 460 \\
Lens & 276 \\
Cucumber & 150 \\
Lettuce & 234 \\
tomato & 226 \\
onion & 170 \\
Cabbage & 293 \\
Pepper & 170 \\
Chard & 378 \\
Parsley & 800 \\
Spinach & 529 \\
Fennel & 430 \\
Sorghum & 351 \\
\hline
\end{tabular}

example, boil, rinse and boil again). This process leaches more potassium from the vegetables than normal cooking methods [37].

For raw vegetables used in salads, it is advised to use original Tunisian salad containing tomatoes, cucumber, onion and peppers. Other vegetables, such as cabbage, should be avoided in salads.

\section{Conclusion}

Our main objective of diet prescription in CKD is to slow chronic renal failure progression and to prevent its metabolic complications such as hyperphosphatemia and hyperkaliemia. Dietary restriction covers three principal components: potassium, phosphorus and sodium.

Potassium restriction needs to avoid certain fruit and vegetables. Phosphorus restriction that needs protein intake restriction should be carefully prescribed to avoid malnutrition. Dietary salt should also be reduced.

The role of the dietician is therefore pivotal in helping to create such a diet. For each patient, the dietician must determine their nutritional state, and take into consideration the patient's individual lifestyle habits. This also involves providing guidance and support to the patient, and their family if required. Nutritional advice should be general but it is important to also adapt the diet to each patient's eating habits to improve adherence rates.

The diet itself must offer an adequate quantity of animal protein, which will provide the body with the essential amino acids for tissue repair, hormone synthesis without inducing phosphorus, and balance the level of sodium or potassium consumption. It's a veritable calculation which must also integrate the patient's requirement for calories, vitamins, amino acids and hormones.

Given the low number of dieticians working in our hospital settings, local authorities need to be made more aware of crucial role played by dieticians. Prevention is far better than treatment. In this perspective, dietary measures must be at the core of our intervention.

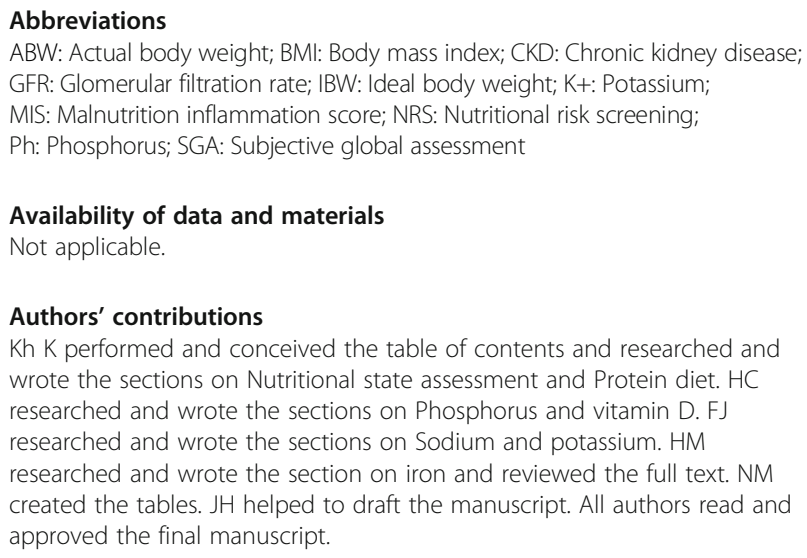

\section{Competing interests}

The authors declare that they have no competing interest.

Consent for publication

Not Applicable.

Ethics and consent to participate

Not applicable.

Received: 27 March 2016 Accepted: 12 January 2017

Published online: 23 January 2017

\section{References}

1. Counil E, Cherni N, Kharrat M, Achour A, Trimech H. Trends of incident dialysis patients in Tunisia between 1992 and 2001. Am J Kidney Dis. 2008; 51(3):463-70.

2. Stel VS, Kramer A, Zoccali C, Jager KJ. The 2007 ERA-EDTA Registry AnnualReport-a Précis. NDT Plus. 2009;2(6):514-21.

3. Barsoum RS. Burden of chronic kidney disease: North Africa. Kidney Int Suppl (2011). 2013;3(2):164-6.

4. Abrahams Z, McHiza Z, Steyn NP. Diet and mortality rates in SubSaharanAfrica: stages in the nutrition transition. BMC Public Health. 2011;11: 801.

5. Méjean C, Traissac P, Eymard-Duvernay S, El Ati J, Delpeuch F, Maire B. Diet quality of North African migrants in France partly explains their lower prevalence of diet-related chronic conditions relative to their native French peers. J Nutr. 2007;137(9):2106-13.

6. Brenner BM. Nephron adaptation to renal injury or ablation. Am J Physiol. 1985;249(3 Pt 2):F324-37.

7. Mitch WE, Remuzzi G. Diets for patients with chronic kidney disease, still worth prescribing. J Am Soc Nephrol. 2004;15(1):234-7.

8. Walser M, Mitch WE, Maroni BJ, Kopple JD. Should protein intake be restricted in predialysis patients? Kidney Int. 1999;55(3):771-7.

9. Mitch WE, Walser M. Nutritional therapy of the uremic patient. In: Brenner BM, Rector FC, editors. The Kidney. Philadelphia: WB Saunders; 2000. p. 2298-340.

10. Pickering WP, Price SR, Bircher G, Marinovic AC, Mitch WE, Walls J. Nutrition in CAPD: Serum bicarbonate and the ubiq-uitin-proteasome system in muscle. Kidney Int. 2002;61:1286-92.

11. William E, Mitch WE, Remuzzi G. Diets for patients with chronic kidney disease, still worth prescribing. J Am Soc Nephrol. 2004;15(1):234-7. http:// www.renal.org/guidelines/modules/nutrition-in-ckd\#SummaryScreening. 
12. Chen J, Peng H, Yuan Z, et al. Combination with anthropometric measurements and MQSGA to assess nutritional status in chinese hemodialysis population. Int J Med Sci. 2013;10(8):974-80.

13. Miladi I, Etat Nutritionnel Chez Les Hemodialyses Depuis Plus De Dix Ans A Propos DE 138 CAS Thesis of medicine. TH/SF3290 2012.

14. Friedman AN, Fadem SZ. Reassessment of albumin as a nutritional marker in kidney disease. J Am Soc Nephrol. 2010;21(2):223-30.

15. Thérond P. Albumine. In: Vassault A, editor. Société Française de Biologie Clinique. Cahier de formation biochimie. Assurance qualité. Tome II. Paris: SFBC; 1994. p. 61-7.

16. Baxter JP. Problems of nutritional assessment in the acute setting. Proc Nutr Soc. 1999:58(1):39-46.

17. Bickford GR, Brugler LJ, Gannon C. Nutrition assessment outcomes: a protocol for Native American hospitals. MLO Med Lab Obs. 2000;32(12):32-7.

18. International Federation of Clinical Chemistry, Shenkin A, Cederblad G, Elia M, Isaksson B. Laboratory assessment of protein-energy status. Clin Chim Acta. 1996;253:S5-59.

19. Shenkin A, Cederblad G, Elia M, Isaksson B. Laboratory assessment of protein energy status. J Int Fed Clin Chem. 1996;9(2):58-61.

20. Tunisian Official journal 22 février 2010. 26 février 2010 Décret n²010-318 p 541

21. Espahbodi F, Khoddad T, Esmaeili L. Evaluation of malnutrition and its association with biochemical parameters in patients with end stage renal disease undergoing hemodialysis using subjective global assessment. Nephrourol Mon. 2014;6(3):e16385.

22. Bigogno FG, Fetter RL, Avesani CM. Applicability of subjective global assessment and malnutrition inflammation score in the assessment of nutritional status on chronic kidney disease. J Bras Nefrol. 2014;36(2):236-40.

23. National Kidney Foundation. K/DOQI clinical practice guidelines for chronic kidney disease: evaluation, classification, and stratification. Am J Kidney Dis. 2002;39(2 Suppl 1):S1-266.

24. Heimbürger O, Qureshi AR, Blaner WS, Berglund L, Stenvinkel P. Hand-grip muscle strength, lean body mass, and plasma proteins as markers of nutritional status in patients with chronic renal failure close to start of dialysis therapy. Am J Kidney Dis. 2000;36(6):1213-25.

25. Fouque D, Vennegoor M, Ter Wee $P$, Wanner C, Basci A, Canaud B, Haage $P$, Konner K, Kooman J, Martin-Malo A, Pedrini L, Pizzarelli F, Tattersall J, Tordoir J, Vanholder R. EBPG guideline on nutrition. Nephrol Dial Transplant. 2007;22Suppl 2:ii45-87.

26. Piccoli GB, Vigotti FN, Leone F, Capizzi I, Daidola G, Cabiddu G, Avagnina P. Low-protein diets in CKD: how can we achieve them? A narrative, pragmatic review. Clin Kidney J. 2015;8(1):61-70.

27. Millward DJ. Identifying recommended dietary allowances for protein and amino acids: a critique of the 2007 WHO/FAO/UNU report. Br J Nutr. 2012; 108 Suppl2:S3-21

28. European Food Safety Authority (EFSA). Parma, Italy SCIENTIFIC OPINION Scientific Opinion on Dietary Reference Values for protein1 EFSA Panel on Dietetic Products, Nutrition and Allergies (NDA)2. 3 EFSA J. 2012;10(2):2557.

29. Harris D, Thomas M, Johnson D, Nicholls K, Gillin A. Caring for Australasians with Renal Impairment (CARI). The CARI guidelines. Prevention of progression ofkidney disease. Nephrol (Carlton). 2006;11 Suppl 1:S2-197.

30. Zarazaga A, García-De-Lorenzo L, García-Luna PP, García-Peris P, LópezMartínez J, Lorenzo V, Quecedo L, Del Llano J. Nutritional support in chronic renal failure: systematic review. Clin Nutr. 2001;20(4):291-9.

31. Malberti F. Hyperphosphataemia: treatment options. Drugs. 2013;73(7):673-88.

32. Beto JA, Ramirez WE, Bansal VK. Medical nutrition therapy in adults with chronic kidney disease: integrating evidence and consensus into practice for the generalist registered dietitian nutritionist. J Acad Nutr Diet. 2014; 114(7):1077.

33. Moore LW, Nolte JV, Gaber AO, Suki WN. Association of dietary phosphate and serum phosphorus concentration by levels of kidney function. Am J Clin Nutr. 2015;102(2):444-53.

34. Echida Y, Mochizuki T, Uchida K, Tsuchiya K, Nitta K. Risk factors for vitamin D deficiency in patients with chronic kidney disease. Intern Med. 2012;51(8): 845-50

35. Ben Romdhane $H$, Ben Ali S, Skhiri $H$, Traissac $P$, Bougatef $S$, Maire $B$ Delpeuch F, Achour N. Hypertension among Tunisian adults: results of the TAHINA project. Hypertens Res. 2012;35(3):341-7.

36. Jarraya F, Kammoun K, Mahfoudh H, Kammoun K, Hachicha J. Management ofarterial hypertension in Tunisia: the challenge of a developing country. Rev Med Suisse. 2012;8(353):1725-6. 1728-30.
37. Burrowes JD, Ramer NJ. Removal of potassium from tuberous root vegetables by leaching. J Ren Nutr. 2006;16(4):304-11.

38. Mason H, Shoaibi A, Ghandour R, O'Flaherty M, Capewell S, Khatib R, Jabr S, Unal B, Sözmen K, Arfa C, Aissi W, Ben Romdhane H, Fouad F, Al-Ali R, Husseini A, MedCHAMPS project team. A cost effectiveness analysis of salt reduction policies to reduce coronary heart disease in four Eastern Mediterranean countries. PLoS One. 2014;9(1):e84445.

\section{Submit your next manuscript to BioMed Central and we will help you at every step:}

- We accept pre-submission inquiries

- Our selector tool helps you to find the most relevant journal

- We provide round the clock customer support

- Convenient online submission

- Thorough peer review

- Inclusion in PubMed and all major indexing services

- Maximum visibility for your research

Submit your manuscript at www.biomedcentral.com/submit
Biomed Central 